\author{
Pawel Szczuraszek \\ mgr inż. budownictwa \\ Biuro Inżynierii Drogowej BID s.c., Bydgoszcz \\ biuro@bid-bydgoszcz.pl
}

DOI: 10.35117/A_ENG_16_06_01

\title{
The Example of decision analysis in choosing a surface type for constructing a segregated cycle facility and footway in a recreational area
}

\begin{abstract}
In the article the author present a proposed method of assessing different types of segregated cycle facility and footway surfaces basing on criteria decision analysis. Subsequently, surface types most commonly used in Europe as well as around the world were chosen and compared basing on the previously established criteria regarding functional, technical and economical characteristics. Further on, an optimal surface type was chosen for a specific segregated cycle facility located in a landscape park with unfavourable groundwater conditions. Similarly, an optimal surface type for footways was chosen. Basing on the reliable results of the analyses, the author formulated conclusions which can be helpful in choosing the appropriate surface type for segregated cycle facilities and footways in different but similar projects.
\end{abstract}

Keywords: Surfaces; Segregated cycle facilities; Footways; Multiple-Criteria Decision analysis; Comparative analysis

\section{Introduction}

Currently the majority of implemented investments in our country is accompanied by infrastructure related to footways and segregated cycle facilities. Construction of a segregated cycle facility is dictated by, inter alia, the growing awareness of the social importance of physical movement on our health, increasing the competitiveness of the bike in terms of time by now firmly overloaded streets of car traffic and the promotion of the protection of the environment. However, still a matter of contentious issue remains the choice of the surface, as the experience of our country in this regard are relatively modest. The number of segregated cycle facilities in our country, compared to the European countries, is still at the level of the minimum. In European cities with the best promotion of the bicycle transport use of bike journeys exceeds 30\%, in Poland, is it at the level of just a few percent [5].

While the implementation of sidewalks, both at the design stage, and the subsequent execution, can be seen in many cases that the main factor which is guided by the investor at the time of their construction or reconstruction, except costs, is their appearance, fitting into the environment. In the background there are such features as: ease of movement by older people or women in high heels, strength of the surface, efficient maintenance during the winter and summer, security.

Currently, the legal framework (Regulation of the Minister of Infrastructure and Development of 17 February 2015 amending regulation on the technical conditions, which should correspond to public roads and their location Dz.U. z 1999r. Nr 43 poz. 430) does not indicate clearly the construction of segregated cycle facilities and footways. It only recalls individual design or according to the common directory structure. However, these are only recommendations, not rigid guidelines. There is a possibility of applying other structures, choosing them according to your task. 
Proper selection of footway, at the design stage is crucial to the functional, technical and economic aspects. In this article the author presents a discussion and try to multi-criteria assessment of different surfaces that can be used on roads designated for cyclists and pedestrians, allowing for choice as the best type of surface. The analysis was made by the author for the construction of roads for pedestrians and cycling trails in Central Park in Olsztyn. Due to the adverse ground and water conditions, he established the need to make a permanent foundation and appropriate to strengthen the ground, which was the starting point in the analysis.

The method of multicriteria evaluation is to include in the assessment of selecting the most favorable conditions many aspects of utility construction and operation of roads. For each of the criteria (collectively appointed 10) was evaluated on the basis of specific data resulting from previous operating experience, or experimental, in terms of numbers on a scale of 1 to 10 , in a subjective way (lowest score $=1$, highest $=10$ ). For all of the criteria adopted at the same weight, and thus the final grade for the type of surface was the direct sum of the marks for each criterion. In contrast, the most advantageous surface was that which achieved the highest total score.

The following criteria were adopted for the analysis of functional characteristics, technical and economic subjects relating to segregated cycle facilities and footways:

1) Energy consumption by users.

2) Travelling in comfort.

3) The construction costs.

4) Maintaining in summer and winter.

5) Realization and exploitation problems.

6) Availability.

7) Public Safety.

8) Aesthetics.

9) Social opinions and national and foreign experiences in the use of different types of surfaces.

In order to implement the above multi-criteria analysis was conducted field observations, which included:

- recognition ground and water conditions;

- monitoring of the existing land use;

- observations concerning the size of the footways and segregated cycle facilities in the nearby environment of the analyzed area;

- direct interview with the inhabitants of the nearby area - their preferences for the type of surface on cycling trails and roads for pedestrians in terms of their usefulness and comfort of travel and the impact of using different types of surface aesthetics and their incorporation in the park area.

\section{Evaluation Of Selected Types Of Cycling Trails Surface}

The choice of the surface for analysis.

Currently in Europe and around the world to build segregated cycle facilities most frequently used surfaces are:

1. asphalt - SMA;

2. "asphalt" with the addition of colouring pigment;

3. concrete paving bevelled; 
4. concrete paving non-bevelled;

5. concrete slabs;

6. concrete;

7. resin or concrete with resins;

8. unbound materials (e.g. stone chippings, gravel).

\section{Energy consumption by users.}

An essential element for segregated cycle facilities users are rolling resistance. Cyclists are more likely to move along the paths, which do not require high energy contribution. Asphalt surfaces, concrete cement and resins seem to be most beneficial in this case. Rolling resistance are the smallest, and at the proper performance the surface does not deform, staying durable and regular over the years. Concrete pavers causes much higher rolling resistance, which means that using the same energy cyclist makes a shorter distance than on these surfaces [3].

More rarely seen in our country surface on segregated cycle facilities is a surface made of a cement-based concrete. Also characterized by a relatively low rolling resistance, provided that the bonding (bonding joints and construction) are made with great care. Similarly rare material for the construction of pavements are concrete slabs. Unfortunately, they create much less convenient for the user journey, than the constant and equal to the asphalt surface, resin or a cement-based concrete [4].

Surface used also for cycling trails, although already becoming increasingly rare is unpaved ground, natural, especially in wooded areas or in parks. Frequently used to mechanically stabilized gravel wedges and three sizes (approx. 15, 22, $32 \mathrm{~mm}$ ). Rolling resistance encountered by the user while driving are much greater than on asphalt or a cement-based concrete or resin, ranging from 150 to up to $200 \%$ [6].

Comparison of different types of segregated cycle facilities for energy by their users and the range of the length of the journey like expending the energy are shown in table 1.[7]

Table 1. Comparison of energy consumption and the available area on the bike depending on the type of surface (based on [7]).

\begin{tabular}{|l|c|c|}
\hline \multicolumn{1}{|c|}{ Rodzaj Nawierzchni } & $\begin{array}{c}\text { Zużycie energii } \\
\text { przez rowerzystę }\end{array}$ & $\begin{array}{c}\text { Dostępny obszar przy } \\
\text { podobnym } \\
\text { wydatkowaniu energii }\end{array}$ \\
\hline Asfaltowa równa & $100 \%$ & $100 \%$ \\
\hline Nierówna asfaltowa & $120 \%$ & $70 \%$ \\
\hline $\begin{array}{l}\text { Betonowa kostka brukowa } \\
\text { niefazowana }\end{array}$ & $130 \%$ & $60 \%$ \\
\hline $\begin{array}{l}\text { Betonowa kostka brukowa } \\
\text { fazowana }\end{array}$ & $140 \%$ & $50 \%$ \\
\hline Tłuczeń klinowany & $200 \%$ & $45 \%$ \\
\hline Tłuczeń nieklinowany & & $25 \%$ \\
\hline
\end{tabular}




\section{Travelling comfort.}

A key factor contributing to the attractiveness and comfort cycling routes are the vibrations to which it is exposed cyclist. In this aspect of the bevelled surface of the concrete paving cause much more discomfort of travel, than the layer from the surface smooth, e.g. asphalt. This has been clearly investigated by means of industrial research tools (approved accelerometer placed on the handlebars and saddle bicycle). This study was conducted in Warsaw by the Bureau of Roads and Transport Authority m. St. Warszawy, Institute of Fundamental Technological Research Polish Academy of Sciences. According to these studies smooth surfaces are the optimal solution for the health and comfort of cyclists, and long cycling trails on the surfaces of the concrete paving bevelled may even cause danger to the health of their users [3].

In terms of ride comfort it is also disadvantageous surface of the concrete slabs, mainly due to existing large-sized joints between the panels, and often jumps between them. On the other hand, pavements with unbound materials, e.g. gravel, crushed stone are the least comfortable to ride, as a consequence of the least liked by the users of cycling segregated cycle facilities. In summer nuisance can become an additional floating dust, and in the autumn-winter season - lingering rain and snow. Vibration felt by the cyclist while driving are much larger even than on surfaces of concrete paving stones bevelled.

Considering the high comfort for the best types of surfaces can be surely asphalt pavements with a cement-based concrete and resin. Properly arranged characterized by high longitudinal equality.

Table 2 summarizes the characteristics in terms of equality between different types of segregated cycle facilities [7].

Table 2. Properties of different types of segregated

cycle facilities regarding to their equality [7].

\begin{tabular}{|l|c|}
\hline \multicolumn{1}{|c|}{ Nawierzchnia } & właściwości \\
\hline Asfaltowa równa & $\begin{array}{l}\text { Wysoka równość } \\
\text { podłużna, gładka }\end{array}$ \\
\hline $\begin{array}{l}\text { Betonowa kostka } \\
\text { brukowa niefazowana }\end{array}$ & Nierówna, gładka \\
\hline $\begin{array}{l}\text { Betonowa kostka brukowa } \\
\text { fazowana }\end{array}$ & Nierówna, wyboista \\
\hline Tłuczeń klinowany & szorstka \\
\hline Tłuczeń nieklinowany & wyboista \\
\hline
\end{tabular}

\section{Construction costs.}

The costs of building cycling trails consists of a number of factors such as the type of material used, adapt to the conditions - soil water, the necessary demolition, earthworks etc.. One of the basic elements of regulating the cost, however, is the type of surface used. For many years there has been 
a sustained lower prices of asphalt in relation to the surface of the concrete paving. Implementation of the surface of mineral -asphalt is also much faster than the layer of concrete paving stones which are laid by hand. Adding a color pigment to the bitumen, but increases the aesthetic value, but significantly increases the cost of construction.

An alternative to asphalt pavements are of a cement-based concrete. Formation of the surface is much faster, and costs much higher. The disadvantage of the use of the surface, however, is a high technological regime in the field of production, transport, installation of concrete mix, as well as the use of specialized equipment in the form of concrete pavers. When using cement concrete pavement with the addition of resins, ie. fast-setting, technological regime is even higher. Also the price of such surfaces is not small.

Applied surfaces of concrete slabs are defective alternative to surface. Only in the best conditions, the surface of the slabs approaches the asphalt or the asphalt concrete. The cost of construction is at the same time close to the surface of concrete blocks.

The cheapest surface is, of course, the surface of the unbound materials. Execution of pavement made of gravel cost three times less than concrete blocks and less than an asphalt surface.

\section{Maintaining in summer and winter.}

An important aspect when choosing the type of surface of each road is its subsequent maintenance. Surface built with concrete paving stones in many cases is unstable, often requires constant care and removal of vegetation that grows (especially chamfered). Concrete pitching is not a durable material and resistant, requires a relatively short time of commissioning of regular repairs. It is confirmed by the team of Cycling Trails in the years 2009 - 2011 audits of the technical state of more than 100 $\mathrm{km}$ of cycling trails national roads in 10 provinces, which clearly shows that none of the utilized cycle tracks made of concrete paving does not meet the applicable technical requirements [3]. Most of them qualify to immediately repair, despite the short period since its construction - the oldest was 6 years old. Concrete pitching is also sensitive to extreme weather conditions, often the autumn winter period causes inconsistencies. The problem may also be water that penetrates the gap between the paving stone and freezing, accelerates erosion of the roadway and partly even foundations. In case of the analyzed Park due to the use of suitably strong and durable foundations, the surface of the paving stone should be fairly stable.

Maintenance of asphalt, as well as concrete and cement resin, with its correct orientation, does not cause much fewer problems. Is a layer of relatively permanent, not requiring significant investment on its renovation. In winter it is easy to maintain and clearing snow. With proper grading , good binding of bituminous layer and distribute the material and the cleaning of loose material, there is practically no "sweating" effect at extremely high temperatures. The problem may occur at the unsuitable arranging of layer. Such surface during the summer plasticized, which can cause permanent deformation.

Probably the big problems with perennial maintaining creates a surface with natural aggregates, eg. made of gravel. In winter, the big problem is the behavior of negotiability road from the pavement. The problem would also be accessible at the surface of the technical services related to the maintenance of the analyzed Park. There is virtually no possibility of regular snow removal. 
To keep high comfort while driving on such a surface, except during the winter, before every spring season the surface should be precisely cleaned with grading and alignment.

\section{$\underline{\text { Realization and exploitation problems. }}$}

With the high technology construction of roads and associated infrastructure even the most common ground and water conditions are not an obstacle for the investment. Properly selecting the base course and, if there is such demand, abscission layer and geosynthetics, there is flexibility in the choice of wearing layer. At present, problems of technical difficulties when arranging each of the analyzed surface practically does not occur.

Although until recently there were difficulties with the arrangement of the narrow sections of a mixture of mineral - asphalt, due to the lack of adequate equipment. Over time, this problem has disappeared and is now mechanically laying cycle paths asphalt SMA has become easier than manually laying concrete paving stones.

In many cases, the surface of the concrete paving stone or concrete slabs are chosen because of the relative ease of its dismantling feature, unlike e.g. an asphalt, cement concrete or resin. Also, infrastructure managers prefer this surface. In practice, under the segregated cycle facilities are laid underground installations. Daily observations and the author's experience show that the dismantling of the surface and re-arrangement is often performed inconsistently with the construction - the base is not concentrated, and after a short time settles. Improper alignment causes inequality and the retention of water. In the case of the analyzed park surface will have to be installed on a permanent foundation, therefore, an argument of "dismantling" of the surface is not really important the assessment.

Segregated cycle facilities with cement concrete are often better solution for low-bearing soils. When the land is lowering, concrete is crushing and it cannot be repaired. However, this disadvantage can be largely reduced by using a solid foundation, as is planned in the analyzed Park. The advantage of such a surface for resistance activities moles and to the destructive impact of tree roots (with the exception of a few species). The undeniable advantages of cement-based concrete pavement should included as well as durability. Positive experiences were observed especially at variable year-round aura. Surfaces of cement-based concrete are resistant to frost, cracking or corrosion. As a result, it was noticed that these surfaces required much less operation of any repairs and renovations [3].

In case of colored asphalt surfaces (with pigment), the condition of the proper implementation is to fulfill requirements for materials: binders, aggregates and type of the mineral asphalt mixture. The application of suitable adhesive, and properly selected aggregate provides a basis for modeling the expected color of mixture. Selected types of application mineral bituminous, ie. asphalt concrete, SMA, a mixture of discrete particle size are compatible with the generally accepted principles of standards and guidelines. One of the advantage of using colored asphalt surfaces from dark surface is the lower absorption of solar energy and reflect most solar radiation. This helps to reduce the temperature of the surface induced by the rays of the sun, which is associated with a reduced risk of ruts.

Similarly high values for operating colored asphalt surfaces have resin surfaces, but they require a certain regime of implementation. 
With the construction of segregated cycle facilities made of concrete slabs, special attention should be paid to the correct and highly accurate arrangement. In case of incorrect implementation, formation of large irregularities between the plates should be expected.

When you decide to build segregated cycle facilities with unbound materials, special attention should be paid to the proper execution of stabilization. In many cases, the incorrect implementation is followed by rapid degradation of surface and its fast overgrowing. Often arise some bulges, which reduce the safety of users. The main factor that may permanently destroy the surface of the aggregate is frost.

\section{Availability.}

Feature of availability of the segregated cycle facilities is one of the main factors that will determine the frequency of usage. With its easy accessibility for users of the segregated cyce facilities, get high attractiveness in the eyes of society and the acceptance of the park as a place to visit. Availability should also be understood through the prism of access by law enforcement service and technical area service.

In connection with mentioned argumentation, clearly you can admit the superiority of the smooth surface (asphalt, cement concrete and resin) over concrete paving stones and concrete slabs, and even more the gravel surface 1 and gravel - crushed stone. When using smooth surface, segregated cycle facility will be available for all users. The surface will not be a barrier for cyclists, regardless of the type of bike and it will increase significantly the attractiveness of the area. The area will be also visited by people on rollerblades. In case of of building layer of concrete paving stones, mainly bevelled, the area will become more burdensome for users. Especially for cyclists moving on bikes with thin and narrow tires.

The application of gravel surface will cause a significant deterioration in the availability of the area to all mentioned types of surfaces. Park will be less likely to viit by cyclists. Troublesome will be also maintenance of the bike path uring a year, which will significantly reduce the attractiveness of the area, and in winter the path may be not available at all.

\section{Public safety.}

Broadly understood safety is strongly correlated with the concept of accessibility. When there are disadvantages associated with traveling and comfort, security level deteriorates. When the areas will not be too often visited as a place of recreation and rest, they will be an ideal location for local vandals.

One of the advantages of concrete paving stone is its bigger coefficient adhesion. This feature is important in the security of users of bicycle paths. This parameter has influence on shorter braking distance. The layer of concrete paving is also characterized by higher structural water absorption. In case of precipitation (assuming the presence two millimeter joints between prefabricated) absorb part of the rainwater. They persist in this way more larger coefficient of friction on the surface. In contrast, on asphalt during the rain, this coefficient decreases much faster, leading to slide [1].

When choosing colored asphalt surfaces, we get a significant improvement in the readability of segregated cycle facilitiy and its better recognition. Colorful surfaces influence on the improvement of visibility, because they reflect $25-100 \%$ of the light. This feature improves 
visibility especially at night and in heavily wooded areas. Its contrasting color with sections for pedestrians will increase safety for cyclists and pedestrians.

Whereas the application of surface made of unbound materials will decrease significantly the safety of its users. Segregated cycle facilities in the park would become less attractive as a place of recreation and relaxation. Such surfaces have a tendency to rapid degradation, rutting and overgrowth of greenery, which may result in a reduced number of its users and thereby reducing their security.

\section{Aesthetics.}

In many of realized investments in Poland you can see extreme approach to aesthetic issue. In the former case it is completely omitted, while in the second case is put almost as a priority, not paying attention to other features.

Cyclists, because of direct contact with the environment, are a group particularly sensitive to aspects of ride comfort and aesthetics. In many cases a decisive influence on the choice of route, have a direct perception of users. Therefore, you should keep in mind the aesthetic demands in order to adjust cycling infrastructure to environment, preserve readability, order and harmony in the public space. You should also try to ensure a positive visual and auditory experience. You can also embody some factors making the ride on bicycle pleasant, e.g. small architecture, appropriate landscape solutions [8]. On the other hand, keep in mind that aesthetics cannot mask aspects related to functionality and pejoratively affecting on the value in use of segregated cycle facilities, they cannot also endanger traffic safety. In mentioned case, it is observed widespread use of concrete paving stone or surface made of natural materials as part of the 'compatible with nature' or historical element. Segregated cycle facility made of less user-friendly materials would change travel preferences and such parts would be omitted by many cyclists. The investment would lose its basic functions.

Application of concrete slabs will result the reduction of aesthetic aspects. Such surfaces do not have a positive influence - usually they make an impression of temporary roads.

Choosing the type of surface for the analyzed investment, when it comes to aesthetics, the use of resin surface, colored asphalt or cement concrete should be taken into account. To create harmony between the area of the park and its surroundings would be best to apply the pavements in color which blends with the environment.

\section{Social opinions, national and foreign experiences in the use of different types of surfaces.}

In most European countries, with significantly developed cycling infrastructure are used only asphalt pavements. In countries where at first were used concrete pavers, now new and upgraded sections are already made of asphalt, more often colored or colored resins. Negative experiences with the use of concrete paving stones (especially bevelled) and its exploitation had i.a. Germany. Many built sections of concrete paving today function as sections of walks permitted only pedestrian and cycling traffic (optional for cyclists) [2].

To confirm the correctness of widespread use of asphalt on the bike paths Danish Road Directorate made a research of satisfaction of users. These indicate that they are acceptable for almost all - Table 3 [2]. 
Table 3. Level of users of cycle paths satisfaction, depending on the type of surface based on the residents of Denmark [2].

\begin{tabular}{|c|c|}
\hline Rodzaj nawierzchni & Procent zadowolonych użytkowników \\
\hline Asfaltowa & $98-100$ \\
\hline Asfaltowa z latami & 44 \\
\hline Betonowa kostka brukowa & 43 \\
\hline Kostka kamienna & 2 \\
\hline
\end{tabular}

It should be also emphasized that in most European countries with high cycling tradition, segregated cycle facilities in the city area are not made of natural aggregates, concrete slabs or concrete with cobblestones.

Whereas in Poland, in many cases, even newly created bike paths are implemented with concrete paving. Very often this is due to, as already stated, the argument dismantling such a structure that facilitates access to technical infrastructure underlying surface. Usually mentioned material is used just out of habit. Despite little experience in the development of cycling infrastructure, there are already very often the dissatisfaction of society associated with the use of concrete paving. The idea of using an asphalt in Poland is supported by absolutely all bicycle associations, i.a. Bydgoszcz, Radom, Poznan, Bialystok, Szczecin, Torun and Zielona Gora, Wroclaw, Warsaw etc. Environment expert also started slowly notice the negative aspects of surface made of concrete paving stone. Main topic of VI National Conference on Roads in Lublin in 2006 was cycling infrastructure [3]. During the conference, new resolution was adopted in which, i.a., calls for deletion provisions of the possibility of using pavement cycling made of concrete paving stones.

To confirm the correctness of of that argument, you can use the example of the Forest Park of Culture and Recreation in Myślęcinek in Bydgoszcz. This area is the largest urban park in Poland, which lies just $3 \mathrm{~km}$ from the city center. The area covers more than 800 hectares. This park comprises both harmonious combination of natural beauty with a richly developed infrastructure, which allows for active relaxation. All sections of hiking and biking are made of asphalt. With high availability for users and high comfort park is the most visited recreation and relaxation area in the region. Another confirmation of the high attractiveness of asphalt is the fact, it was used on the most representative streets of the world, such as. Avenue des Champs Élysées and Rue St. Michel in Paris, Bahnhofssstraße in Zurich. In many historical places, footways and pedestrian surface is propeer to character of the area (stone paving stones, slabs), while deliberately on the segregated cycle facilities is used asphalt surface (e.g. Market Main Street in Kosice, Hlavna) [3].

Both european and national experience shows that cyclists do not want to use a segregated cycle facilities made of concrete paving stones surface, especially bevelled, and if possible, often move roadway in direct contact with cars, despite the existing path [3]. Opinions about asphalt are very positive, hence the surfaces are much more common in West Europe. A frequently used surface on bike paths is also colored decorative concrete or colored resins.

From direct interview, which was conducted among residents of the analyzed city for to needs of this analysis, conclusive opinions were achieved. The most desired surfaces are first of all 
ensuring large comfort of movement and which harmonize with environment, provide a positive experience visual and auditory, are legible, preserve order and harmony of the urban space. Some environmental factors, that make a trip pleasant were also desired e.g., through a small architecture, benches, appropriate solutions landscape.

The choice of most advantageous type of pavement for segregated cycle facility.

On the basis of discussion and argumentation was determined the assessment of particular eight types of surface considered from the point of view of 10 analyzed criteria. Table 4.

Table 4. Final results of comparative analysis the different types of segregated cycle facilities.

\begin{tabular}{|c|c|c|c|c|c|c|c|c|c|c|}
\hline \multirow[b]{2}{*}{$\begin{array}{c}\text { RODZAJ } \\
\text { NAWIERZCHI }\end{array}$} & \multicolumn{9}{|c|}{ RODZAJ KRYTERIUM } & \multirow[b]{2}{*}{$\begin{array}{c}\text { SUMA } \\
\text { PUNKTÓW } \\
\text { (POZYCJA } \\
\text { W } \\
\text { RANKINGU) }\end{array}$} \\
\hline & 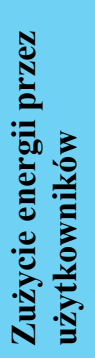 & 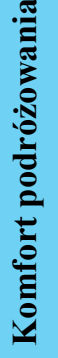 & 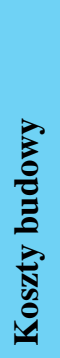 & 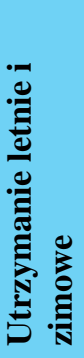 & 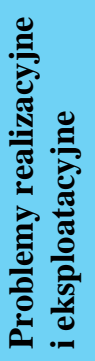 & 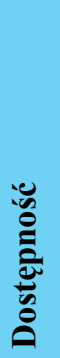 & 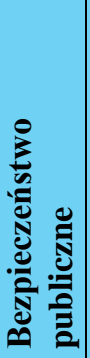 & $\frac{\pi}{\frac{\pi}{2}}$ & 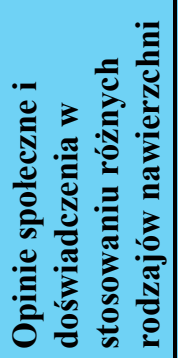 & \\
\hline Asfaltowa & 10 & 10 & 8 & 10 & 10 & 10 & 9 & 7 & 10 & 84 (I) \\
\hline $\begin{array}{c}\text { Asfaltowa z } \\
\text { dodatkiem } \\
\text { pigmentu } \\
\text { koloryzującego }\end{array}$ & 10 & 10 & 2 & 10 & 10 & 10 & 10 & 10 & 10 & 82 (II) \\
\hline $\begin{array}{c}\text { Z betonowej } \\
\text { kostki fazowanej }\end{array}$ & 5 & 3 & 1 & 6 & 6 & 5 & 5 & 5 & 3 & 39 (VII) \\
\hline $\begin{array}{l}\mathrm{Z} \text { betonowej } \\
\text { kostki } \\
\text { niefazowanej }\end{array}$ & 7 & 7 & 1 & 8 & 8 & 8 & 8 & 7 & 6 & $60(V)$ \\
\hline $\begin{array}{c}\mathrm{Z} \text { płyt } \\
\text { betonowych }\end{array}$ & 7 & 5 & 1 & 7 & 4 & 6 & 6 & 1 & 3 & $40(V I)$ \\
\hline betonowe & 10 & 10 & 7 & 10 & 9 & 8 & 8 & 9 & 9 & 80 (IV) \\
\hline $\begin{array}{c}\mathrm{Z} \text { żywic lub } \\
\text { betonowe } \mathrm{z} \\
\text { dodatkiem żywic }\end{array}$ & 10 & 10 & 2 & 10 & 10 & 10 & 10 & 10 & 10 & 82 (II) \\
\hline $\begin{array}{l}\text { Z materiałów } \\
\text { niezwiązanych }\end{array}$ & 1 & 1 & 10 & 1 & 1 & 1 & 1 & 3 & 1 & 20 (VIII) \\
\hline
\end{tabular}

It should be noted, that the estimation of construction costs were taken into account only the implementation of the wear layer. Due to occurring in the the analyzed park landscaped difficult ground and water conditions, accepted the need for a permanent foundation, a filtering layer, a geotextile and soil replacement, regardless of of the upper layer surface. The evaluation was not taken into account costs associated with the lower layers, because their cost is similar.

On the basis of final results of the comparative analysis, you can clearly indicate that most preferred would be asphalt surface. Similarly, high scores had also asphalt surface with the addition of coloring pigment and resin surface. They probably have much greater aesthetic qualities, but 
their negative feature is more than twice the price of asphalt without color additive. To group of top-rated types of surface belongs also surface made of cement concrete.

On the analyzed segregeted cycle facility it is absolutely not recommended to use the surface made of concrete paving stones and concrete slabs bevelled, and even more natural aggregates. Surface of natural aggregates from the point of view of seven of the ten criteria received the lowest scores, and its total rating is only $24 \%$ of the best surfaces' mark. It should be also noticed that the surface of the concrete paving non-bevelled received over a half worse assessment of four best surfaces.

\section{Assessment of selected types of pavement surfaces}

The most frequently used types of pavement surfaces may include:

1. concrete paving bevelled.

2. concrete paving non-bevelled.

3. paving stone (usually granite).

4. sidewalk concrete tiles.

5. paving stone tiles.

6. unbound materials (natural aggregates).

7. asphalt (asphalt concrete, SMA).

8. resin.

In case of pedestrian functional requirements, technical and economic conditions in a very large extent are consistent with the requirements desired for segregated cycle facility surface. It is clear that, e.g. the surface of the pavement is smoother, the less energy input a pedestrian has to put to cross the part of route. The more irregular shape will have a surface, the greater difficulty in moving along it will cause. The least comfortable surface will undoubtedly be pavement of unbound aggregates. Whereas the surface, which will result less power consumption will be surfaces: asphalt, cement concrete and resin. Smooth pavement also provide a higher standard of pedestrian movement and a greater sense of security. There are also barriers to be overcome by those not fully abled, the elderly and women in heels. An exception is, however, asphalt surfaces, which have a relatively low softening point and high air temperatures may cause discomfort pedestrian.

In most road investments assigned for pedestrian, realization costs are a crucial investors ${ }^{6}$ selection criteria. Often, not paying attention to the quality, are made the longest parts assuming a worse technology, save on materials, using all sorts of alternatives. This is the wrong approach. Using worse,less durable materials at the stage of imlementation seems to save money stage, but in the use phase and current maintenance costs rise significantly. Frequent repairs and maintenance of during a year absorb a significant portion of the budget, that could be spent on new goals.

In Poland, the most common pavement sections are pavement made of concrete paving tiles or concrete paving. It is noticeable, especially in new investments, the use of more friendly pavemnents for users, e.g. of concrete paving non-bevelled or paving tiles.

Positive opinions will always be associated with the quality of used materials, comfort, attractiveness of the area and its full availability. Pedestrians, as well as cyclists, due to the direct contact with the environment are a group particularly sensitive comfort ride and aesthetics aspects. In many cases a huge influence on the choice of destinations are connected with of users feelings. 
In European countries, pavements made of natural aggregates are usedvery rarely. Whereas the more frequent surface, especially in recreational areas, leisure, parks, alleys, are decorative surfaces made of cement concrete or resin. Experience with this kind of surface is very positive. At high realizations can be achieved considerable savings. The surface of the poured concrete cement or resin with odciskanym model can fully satisfy everyone. Through the use of various additives you can practically get any color and texture.

\section{Selection of optimal type of pavements for pedestrian section.}

Table 5 summarizes assigned to particular pavements assessment from the point of view of the criteria considered on the basis of the discussion. As in the case of cycle paths taken into account in assessing the costs, only the net cost of execution of the wearing course.

Based on the results of the multi-criteria analysis can indicate the type of pavements the most beneficial on premises of the Park. The highest ranking position achieved undoubtedly pavement of the resin. As the high marks received the surfaces of concrete paving bezfazowej and paving tiles concrete and stone. Whereas the very bad score in the presented analysis received surfaces of concrete paving stones and asphalt bevelled. Absolutely the lowest - surface made of natural aggregates.

Table 5. Results of a comparative analysis the optimal choice of surface footways sections.

\begin{tabular}{|c|c|c|c|c|c|c|c|c|c|c|}
\hline \multirow[b]{2}{*}{$\begin{array}{c}\text { RODZAJ } \\
\text { NAWIERZCHI }\end{array}$} & \multicolumn{9}{|c|}{ RODZAJ KRYTERIUM } & \multirow[b]{2}{*}{$\begin{array}{c}\text { SUMA } \\
\text { PUNKTÓW } \\
\text { (POZYCJA W } \\
\text { RANKINGU) }\end{array}$} \\
\hline & 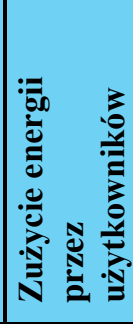 & 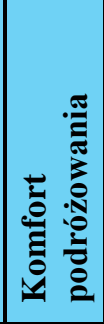 & 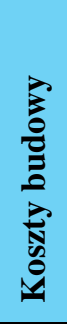 & 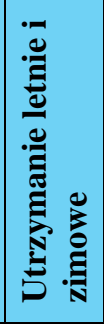 & 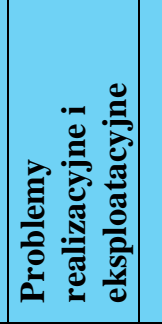 & 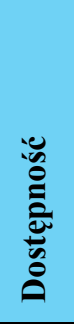 & 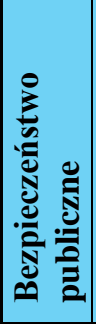 & 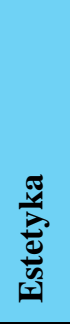 & 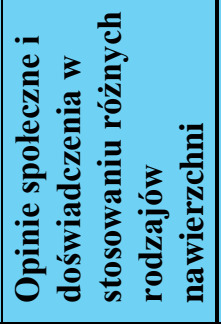 & \\
\hline $\begin{array}{c}\text { Z kostki } \\
\text { betonowej } \\
\text { fazowanej }\end{array}$ & 5 & 3 & 4 & 6 & 6 & 7 & 8 & 6 & 6 & $51(\mathrm{VII})$ \\
\hline $\begin{array}{c}\text { Z kostki } \\
\text { betonowej } \\
\text { bezfazowej }\end{array}$ & 9 & 9 & 4 & 7 & 7 & 10 & 10 & 10 & 10 & 76 (II) \\
\hline $\begin{array}{c}\text { Z kostki } \\
\text { kamiennej }\end{array}$ & 7 & 7 & 1 & 8 & 7 & 10 & 10 & 10 & 9 & $69(V)$ \\
\hline $\begin{array}{c}\mathrm{Z} \text { chodnikowych } \\
\text { płytek } \\
\text { betonowych }\end{array}$ & 8 & 9 & 5 & 6 & 7 & 10 & 10 & 9 & 8 & 72 (III) \\
\hline $\begin{array}{c}\mathrm{Z} \text { chodnikowych } \\
\text { płytek } \\
\text { kamiennych }\end{array}$ & 8 & 9 & 1 & 7 & 8 & 10 & 10 & 10 & 9 & 72 (III) \\
\hline $\begin{array}{c}\mathrm{Z} \text { materiałów } \\
\text { niezwiązanych } \\
\text { (kruszyw } \\
\text { naturalnych) } \\
\end{array}$ & 1 & 1 & 10 & 1 & 1 & 1 & 1 & 3 & 1 & 20 (VIII) \\
\hline Asfaltowe & 10 & 4 & 1 & 10 & 10 & 7 & 10 & 1 & 5 & $58(\mathrm{VI})$ \\
\hline Z żywic & 10 & 10 & 4 & 10 & 8 & 10 & 10 & 10 & 10 & 82 (I) \\
\hline
\end{tabular}




\section{Conclusion}

The presented discussion and multi-criteria analysis was to identify the most favorable type of pavement on segregated cycle facilities and footways in the specific city park. It should be noticed, however, that the results of these considerations can also be used for other investments, assuming similar ground and water conditions and nature of the environment.

Through a detailed discussion of the issues and a comparison of different types of pavements, indicating their disadvantages and advantages in relation to individual criteria, it seems that the analysis results were achieved on reliable choice pavements. From these results it can be concluded:

1. Definitely the worst solution for ceating new segregated cycle facilities and footways is to use natural or artificial unbound aggregates.

2. For segregated cycle facilities the best choice would be asphalt pavement. If financial resources permit investor suggests to make the pavements with the addition of red pigment, or carrying the surface of the resin, which will considerably increase the aesthetics aspects and durability of the pavements.

3. In relation to the sidewalks best solution seems to be carrying the surface of the resin. The positive effect is obtained by performing this pavements with non-bevelled best at a contrasting color to the road cycling concrete paving stone or tile paving concrete or stone.

\section{Source materials}

[1] Artykuł czasopismo BRUKBIZNES nr 3/2012 „Nawierzchnie ścieżek rowerowych - asfalt vs. betonowa galanteria drogowa”. Śmiertka, Kaczmarek-Kalisz,

[2] Collection of Cycle Concepts Vejdirektoratet, Kopenhaga 2000.

[3] Opinia sprawie typowych nawierzchni dróg dla rowerów. GDDKiA, Departament Studiów, Wydział Studiów w Krakowie, Zespół ds. ścieżek (Dróg) rowerowych. Warszawa - Kraków, luty 2012r.

[4] Postaw na rower. podręcznik projektowania przjazdnej dla rowerów infrastruktury. C.R.O.W. oraz ZG PKE - Miasta dla rowerów. Kraków 1999.

[5] Ruch rowerowy w Polsce na tle innych krajów UE- Raport Wstępny. GDDKiA Departament studiów Wydział Studiów w Krakowie, Zespół ds. Ścieżek Rowerowych. Warszawa - Kraków, czerwiec 2009r.

[6] Standardy techniczne dla infrastruktury rowerowej miasta Krakowa. Pracownia Edukacji Marcin Hyła dla urzędu miasta Krakowa. Kraków 2004.

[7] UPI-Bericht 41: Entwicklung und Potentiale des Fahrradverkehrs - Maßnahmen zur Ausschöpfung des Fahrradpotentials in der Verkehrsplaunung, 2000.

[8] Wytyczne do planowania, projektowania i utrzymania dróg rowerowych w Łodzi. Załącznik do uchwały Rady Miejskiej w Łodzi z dnia 25 czerwca 2009 roku. 